\title{
ISSUES RESULTING FROM THE USE OF THE CRISIS MANAGEMENT TERMINOLOGY IN THE CZECH LEGAL FRAMEWORK
}

\author{
Marek SMETANA ${ }^{1}$, Karel ZDRÁHAL ${ }^{2}$
}

Review article

The crisis management terminology used in the Czech legal framework is not consistent.
Not only the terms are used inconsistently but legal definitions of the terms are not
consistent either. And the inconsistency is most serious in terms defined by laws and
regulations. Each law or regulation uses the terminology in a specific way and it is, in
fact, impossible to convey the meaning of the terms between the laws and regulations.
Consequently, the meaning of each term should be taken on the basis of how the term
is used in a specific context. Anyway, the terms in the crisis management are used in an
unpredictable way.
Crisis management, terminology, legal framework, risk.

\section{Introduction}

The crisis management ranks among young disciplines where the terminology is rather variable. The reason is, in particular, the fact that the crisis management comprises approaches to special natural, anthropogenic, social, economic or corporate management events. As a result, individual departments and experts created (and still are creating) their own terms. Generally, the terms used in the crisis management might have different meanings in some cases, or may even contradict each other or are problematic or unsuitable in terms of etymology. These are, in particular, the various forms of the following terms: crisis, crisis management, danger, threat, jeopardy, risk, risk management or risk analysis.

\section{Results}

\section{Terminologický chaos}

Emil Antušák and Zdeněk Kopecký wrote in their book entitled Úvod do teorie krizového managementu ("Introduction into the Theory of Crisis Management”) (Antušák \& Kopecký, 2003) that the term "crisis management" appeared for the first time during the Cuban Missile Crisis in 1962 during a conflict between the U.S.A. and U.S.S.R. when the U.S.S.R. decided secretly to install its missiles in Cuba. The U.S. President J. F. Kennedy used this name for a working commission, the task of which was to restrict risks of confrontation between the U.S.A. and U.S.S.R. Later on, the general public started hearing this term mainly in information about potential military conflicts. (Antušák \& Kopecký, 2003). After the collapse of the Communist Block, this term started appearing, in addition to military threats, in a non-military context, acquiring the approximate meaning which is perceived now.

In the Czech Republic, this term appeared, in the non-military context, even later, the legal framework mentioning it for the first time as late as in the year 2000. Because this term has been used for a short time only, the usage has not been consistent yet. Even the translation into Czech language is an issue and more problems appear after individual documents from among the Czech legal framework are studied. There is a number of present-day definitions of the crisis management in professional literature. For instance:

- "The crisis management is typically understood as a set of measures, the aim of which is to manage extraordinary or crisis situation where such actions are taken by state administration/local authority officials or managers who are responsible for a specific area or production in the national or international scale“ (Horák, 2004).

- "The crisis management is a process of managing the crisis. In a wider sense, the crisis management comprises three elements which support each other: the dialogue, cooperation and ability to face a crisis". (Antušák \& Kopecký, 2003).

- Or the definition from the Act on Crisis: "The crisis management is a total of managing activities conducted by crisis management bodies focused on the analysis and evaluation of safety risks, and planning, organization, performance and supervision of activities carried out within:

- preparation for crisis situation or dealing with crisis situations, or

- protection of critical infrastructure".

VŠB - Technical University of Ostrava, Faculty of Safety Engineering, Ostrava, Czech Republic, marek.smetana@vsb.cz

2 Fire Rescue Service of the Zlín Region, Regional Office in Kroměřǐz, Czech Republic, zdrahal.karel@gmail.com 
As mentioned above, the inconsistency of the terms used throughout laws and regulations is of major consequence. It makes the multidisciplinary approach difficult and sometimes even impossible. The body of Czech Laws (that is to say, the Collection of Laws) mentions the terms „crisis management", „crisis planning" and ,a crisis plan") consistently and only in the context of the Crisis Act (this means, the regulations mention the Crisis Act in relation with the terms, or the meaning of the terms is clear in the context). Generally, if the laws govern a set of activities typical for the crisis management, it is not mentioned expressly that the system is that of the crisis management (a typical example of such an approach is the chemical industry or environmental protection).

Other important terms relating to the crisis management, such as the terms connected with the danger, threat or jeopardy, are defined by laws seldom only and their meaning might be derived on the basis of a particular use (for instance, from definitions of other terms). When mentioned, intuition is mostly used. In general, a conclusion can be still drawn that the terms are used in accordance with the causal link: danger - threat (jeopardy) - risk. Or the terms „danger“ and "threat" can be interpreted similarly or any of these terms (,danger", „threat") is not used in the system. For instance, in the area of accident prevention, only the term ,danger" is used.

\section{The problem with the definition of risk}

It is, in particular, the term "risk" that is interesting. This term is the basis for risk management along with the terms ,risk analysis“, „risk management“, „risk assessment“, or „risk control“". Smejkal and Rais (Smejkal \& Rais, 2006) mention that a lot of interpretations exist now which interpret the term ,risk“. Some definitions try to describe the phenomenon in terms of quality, while others attempt to quantify the risk. Below are some definitions (Smejkal \& Rais, 2006):

- A risk is a situation when a negative deviation might occur from the desired and expected situation.

- A risk is the existence of a chance that planned (or assumed) intentions and activities will be different from reality.

- A risk is a term which describes the fact that any human activity is connected with a possible loss, failure, damage, breach of stability or breach of safety.

In strategic documents and laws, following definitions can be found:

- Safety strategies:

- A risk is a chance that there is a certain probability of a situation which is regarded as undesirable in terms of safety. The risk can be always derived and deduced from a particular threat. The degree of risk, which means the probability of hazardous consequences resulting from the threat and vulnerability of the interest, can be evaluated on the basis of a risk analysis which is based on the assessment of our preparedness and readiness to face such threats. (Safety Strategy of the Czech Republic).

- Management of information technology and information system security:

- The risk is a combination of the probability of an undesirable event, and the consequences of such event, if any (ČSN, 2006).

- The risk is a potential chance that the threat will make use of the vulnerability of assets, resulting, thus, in the loss or damage of assets. (ČSN, 2002).

- Economic risks and management of companies:

- A risk in the management of companies expresses uncertainty (what might happen) as well as goals (what should be accomplished), describing thus the degree of threat as well as that of opportunities. (Zuzák \& Konigová, 2009).

- A risk is what may happen and the consequences of what happened for the accomplishment of goals. (ČSN, 2009).

- Hazardous chemical substances:

- A risk is given by a probability of negative effects which may occur under pre-defined exposure. (Act, 2003).

- A risk is a probability of undesirable specific effects occurring during certain time or under certain circumstances. (Act, 2006a).

Having listed the definitions, it is clear that formulations are really different in various laws, strategic documents or special texts. When comparing them, the term ,risk“ appears to be typically (but not always) explained as ,combination of the probability of a negative phenomenon and the consequences of such phenomenon" (the compliance being biggest for this meaning of the term). Doc. Janošec published the definition which, on the contrary, defines risk as "an expression of the probability of threats" only (Janošec, 2010), and so not in relation to the amount of its consequences. It is based on the formula:

$$
R I Z I K O=\frac{(\text { Hrozba }) \times(\text { Zranitelnost }) \times(\text { Hodnota })}{\text { Protiopatreni }}
$$

(Janošec, 2010)

This perspective then adds another, new view of risk. 
In practice, such deviations may cause, and cause, bureaucracy to grow extremely. This is, in particular, the case of the preparation of plans and other safety documentation. Thanks to various definitions not only of this term, it is impossible to merge documents from various areas into a single document. The process of controlling situations where damage might occur directly or situations where damage is being suffered now is very similar but, when preparing for such contingency, the process is duplicated for various areas and associated definitions.

\section{Other terms in relation to risk and problems with the definitions}

In case of the terms "risk management, ,risk analysis“, ,risk assessment", „risk evaluation“ and „risk control", the situation is more complicated and the definition almost do not coincide. Typically, the terms overlap with other terms or the terms are defined ,too widely“... (for instance, the risk analysis in one system comprises also evaluation (assessment) of risks, while the risk assessment in another system is a process which follows the risk analysis).

Legal regulations which govern the crisis management system typically do not define crisis events or situations: "either a probability of a crisis event is mentioned or should be considered" or a legal regulation specifies (defines) an event which is not identified as a "crisis" event, but has a nature of a crisis event and is a subject, though not expressed explicitly but defined in fact, of a crisis management system. In this case, no difference is often made between a crisis situation and emergency.

Regarding the crisis planning documentation, the terms are very different and the term "crisis plan" is used in connection with the Crisis Act only.

It is impossible to describe generally the heterogeneity of terms used in the crisis management. A detailed overview of the terms would be also very extensive.

The crisis management is close, by its nature, to the IT/IS security. The terminology in laws and regulation is, however, different there. Certain similarities can be traced in the meaning of the individual terms. For instance, an emergency corresponds to a security incident. The term ,crisis situation“ is used without being specified in detail (it follows from the logics in the context that a crisis situation occurs, if a safety incident reaches a certain level of relevance). The terms "danger" and "jeopardy" are almost not used. Typical terms used there include ,threat", „risk“" and „risk analysis“ which are explicitly defined, in particular, by standardized technical documents. In laws and directives, implicit definitions prevail or the meaning of terms can be derived from their use.
Another interesting and related area is the chemical industry and living environment. At the level of the legal framework, this area represents an extensive set of regulations. For the sake of simplicity, the regulations can be broken down into following groups:

- water and water management,

- air,

- wastes,

- chemical substances and agents,

- prevention of major incidents,

- integrated pollution prevention and restriction,

- environment impact assessment (EIA institute).

Legal regulations define many terms which can be used as the terms in the crisis management. They include, for instance: vulnerable areas, hazardous nature of substances and agents, risk, environment risk assessment, source accident, identification of hazard, risk characteristics, risk assessment, environment damage, risk element, risk-involving substance, hazard for public health, harmful substances, accident, emergency plan, smog situation, dangerous substances, dangerous agents, major accident, source of risk (hazard), risk analysis and many other terms.

In general, the terms are defined in the regulation without considering (evidently) definitions of the same or similar terms in other legal regulations. Let us take, as an example, two terms: „hazardous substances“ and „harmful substances“. On one hand, according to the Act on Chemical Substances and Chemical Agents (Act, 2003), "the hazardous substances or hazardous agents are the substances or agents which, under terms defined in the Act, feature at least one hazardous property and because of such property they are classified as explosive, toxic, extremely flammable, highly flammable, flammable, highly toxic, toxic, harmful to health, caustic, irritant, sensitizing, carcinogenic, mutagenic, toxic for reproduction or dangerous for the environment. On the other hand, the Water Act (Act, 2001) as amended defines harmful substances as "the substances which are not wastewaters or mining waters and which may degrade the quality of surface water or groundwater". It is clear that this is a subset and the harmful substances are also the hazardous substances. The only difference is the text „under terms defined in the Act“. Because of the parallel definitions, "prevention plans for harmful substances" (dealing with prevention, leakage, and the liquidation of accidents) as well as ,emergency plans" (which are more or less the same, maybe slightly more specialized) co-exist in practice. 


\section{Conclusion}

Finally, it should be pointed out that the terminology related to the crisis management should be always understood and viewed in the context of particular law or regulation in force. Generally, the meaning of the terms cannot be transferred into areas which are governed by other laws and regulations. Without unifying the definitions at the level of basic terminology, it is impossible to consider the unification of actions aimed at the preparation or management of crisis management events (in any affected area). And such is the situation in spite of the fact that at the level of processes this would be just variants of a single general-purpose scheme which, however, does not exist so far.

\section{Acknowledgements}

This study was supported by the Research plan No.VG20102015043 "Simulation of crisis management processes in the system of the lifelong learning of Integrated Rescue System units and public service bodies", which is financed by the Ministry of interior of the Czech Republic. (Security Research for the Needs of the State 2010-2015 (2010-2015)).

\section{References}

ANTUŠÁK, Emil, KOPECKÝ,Z deněk (2003). Úvod do teorie krizového managementu. 1. vyd. Praha: Oeconimica, 2003. 96 s. ISBN 80-245-0340-9.

ČSN ISO/IEC TR 13335:2002. Informační technologie - Směrnice pro řzizení bezpečnosti IT 1-3.

ČSN ISO/IEC 27001:2005. Informační technologie - Bezpečnostní techniky - Systémy managementu bezpečnosti informaci - požadavky.

ČSN ISO/IEC 17799:2006. Informační technologie - Soubor postupů pro management bezpečnosti informací.

ČSN BS 25999-1:2009. Management kontinuity činností organizace - Část 1: Soubor zásad.

HORÁK, Rudolf et al. (2004). Průvodce krizovým ř́zením pro veřejnou správu. 1. vyd. Praha: Linde Praha, 2004. 407 s. ISBN 80-7201-471-4.

JANOŠEC, Josef (2010). Hrozba a riziko v bezpečnostní terminologii. In Krizový management: sborník. Pardubice: Univerzita Pardubice, 2010, s. 40-52. ISBN 798-80-7395-304-1.

SMEJKAL, Vladimír, RAIS, Karel (2006). Řizení rizik ve firmách a jiných organizacích. 2. vyd. Příbram: Grada Publishing, 2006. 300 s. ISBN 80-247-1667-4.

ZUZÁK, Roman, KONIGOVÁ, Martina (2009). Krizové řizení podniku. 2. vyd. Havlíčkův Brod: Grada Publishing, 2009. 256 s. ISBN 978-80-247-3156-8.

Zákon č. 17/1992 Sb. (1992), o životním prostředí, ve znění pozdějších předpisů.

Zákon č. 239/2000 Sb. (2000a), o integrovaném záchranném systému, ve znění pozdějších předpisů.

Zákon č. 240/2000 Sb. (2000b), o krizovém ř́zení a o změně některých zákonů (krizový zákon), ve znění pozdějších předpisů.

Zákon č. 241/2000 Sb. (2000c), o hospodářských opatřeních pro krizové stavy, ve znění pozdějších předpisů.

Zákon č. 365/2000 Sb. (2000d), o informačních systémech veřejné správy a o změně některých dalších zákonů, ve znění pozdějších předpisů.

Nařízení vlády č. 462/2000 Sb. (2000), k provedeni § 27 odst. 8 a § 28 odst. 5 zákona č. 240/2000 Sb., o krizovém řizení a o změně některých zákonů (krizový zákon), ve znění pozdějších předpisů.

Zákon č. 100/2001 Sb. (2001a), o posuzování vlivů na životní prostředí, ve znění pozdějších předpisů.

Zákon č. 185/2001 Sb. (2001b), o odpadech a o změně některých dalších zákonů, ve znění pozdějších předpisů.

Zákon č. 254/2001 Sb. (2001c), o vodách a o změně některých zákonů (vodní zákon), ve znění pozdějších předpisů.

Zákon č. 86/2002 Sb. (2002), o ochraně ovzduší a o změně některých dalších zákonů, ve znění pozdějších předpisů.

Vyhláška č. 356/2002 Sb. (2002), kterou se stanoví seznam znečištujících látek, obecné emisní limity, zpusob předávání zpráv a informací, zjištování množství vypouštěných znečištujících látek, tmavosti kouře, prípustné míry obtěžování zápachem a intenzity pachů, podmínky autorizace osob, požadavky na vedení provozní evidence zdroju znečištováni ovzduši a podminky jejich uplatňování, ve znění pozdějších předpisů.

Zákon č. 356/2003 Sb. (2003), o chemických látkách a chemických prípravcích a o změně některých zákonů, ve znění pozdějších předpisů. 
Vyhláška č. 223/2004 Sb. (2004), kterou se stanoví bližší podmínky hodnocení rizika nebezpečných chemických látek pro životní prostředi, ve znění pozdějších předpisů.

Zákon č. 127/2005 Sb. (2005a), o elektronických komunikacích a o změně některých souvisejících zákonů (zákon o elektronických komunikacích), ve znění pozdějších předpisů.

Vyhláška č. 523/2005 Sb. (2005b), o bezpečnosti informačních a komunikačních systémů a dalšich elektronických zařizení nakládajících s utajovanými informacemi a o certifikaci stínicích komor, ve znění pozdějších předpisů.

Zákon č. 59/2006 Sb. (2006a), o prevenci závažných havárií způsobených vybranými nebezpečnými chemickými látkami nebo chemickými př́pravky, ve znění pozdějších předpisů.

Vyhláška č. 256/2006 Sb. (2006b), o podrobnostech systému prevence závažných havárií, ve znění pozdějších předpisů. 